\title{
HEAT BALANCE IN MODERN AUTOMOTIVE ENGINES
}

\section{KAREL PÁV}

ŠKODA AUTO a.s., Mladá Boleslav 293 60, Tel.: 326815 450, E-mail: karel.pav@skoda-auto.cz

VÁCLAV RYCHTÁ̊̆

ŠKODA AUTO a.s., Mladá Boleslav 293 60, Tel.: 326818 251, E-mail: vaclav.rychtar@skoda-auto.cz

VÁCLAV VOREL

ŠKODA AUTO a.s., Mladá Boleslav 293 60, Tel.: 326818 252, E-mail: vaclav.vorel@skoda-auto.cz

\section{SHRNUTI}

Tento príspěvek obsahuje informace o přerozdělení tepla v současných vozidlových spalovacích motorech. Vycházelo se z různých konstrukcí především zážehových motorů s rozdílnými zdvihovými objemy, vznětové motory jsou však také zmíněny. Je zde uveden postup výpočtu tepelné bilance motoru, stejně tak, jako obtiže spojené se získáním vstupních dat měěením. Byl navržen a ověřen empirický vztah pro výpočet tepelného toku do chladící kapaliny, který umožňuje snadné nalezení nekorektně změřených pracovních bodů motoru už v počáteční fázi automatického měříího cyklu. Naměřené hodnoty byly srovnány s výpočtem pomocí programu GT-Power. Na závěr je uvedeno srovnání různých typů motorů s ohledem na velikost tepelného toku do chladící kapaliny.

KLIĆCOVÁ SLOVA: ZÁKON ZACHOVÁNÍ ENERGIE, ÚČINNOST HOŘENÍ, ZBYTKOVÉ TEPLO, TEPELNÝ TOK DO CHLADÍCI KAPALINY

\section{ABSTRACT}

This paper provides information about the heat distribution in modern automotive engines. It takes into account several gasoline engines of different designs and swept volumes. The energy balance of $\mathrm{Cl}$ engines is also mentioned briefly. A method for heat flux calculation is introduced as well as the difficulties associated with the taking of measurements. An approximation formula for the heat flux to coolant, which helps identify irregular points even during the early phase of automated measurement sequence, has been developed. The measured results are compared with the calculated values using the GT-Power simulation tool. At the end, the benchmark of different engines types regarding the heat flux to coolant is shown.

\section{KEYWORDS: ENERGY CONSERVATION, COMBUSTION EFFICIENCY, RESIDUAL HEAT, HEAT FLUX TO COOLANT}

\section{INTRODUCTION}

The engine energy balance is a very important factor for engine development. Knowledge of the heat flux to the coolant is crucial for subsequent cooling and car front-end development. It is generally known that measurement results are strongly linked to the accuracy of the measured quantities. In particular, the temperature error has a significant influence on the calculated heat flux to the coolant. The measurement itself is time consuming, typically taking several hours. On-line detection of the measurement error would therefore be very useful. A lot of measurements have been carried out primarily in relation to naturally aspirated gasoline engines. Considering the amount of measurements, the calculation of statistical results is possible. These results can serve to create bounds for regular operation. Then the irregular measured points standing out of this area can be removed or investigated in detail.

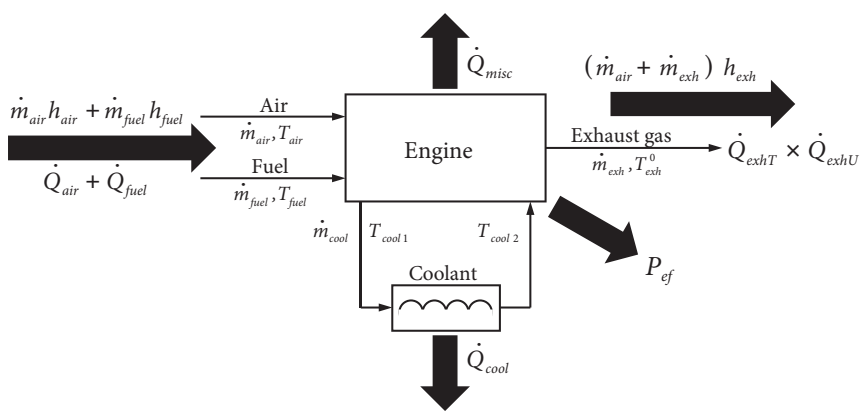

FIGURE 1: Schematic of fundamental heat flows.

OBRÁZEK 1: Schématické znázornění základních tepelných toků. 


\section{ENERGY CONSERVATION}

A schematic representation of particular heat flows can be shown in a simplified form as introduced in Figure 1. This indicates the essential heat flows and effective power only, not considering a turbocharged engine.

The stated stationary heat flows can be expressed by the following equations. Input energy flow is given by the sum of the air and fuel total enthalpies.

$\dot{Q}_{\text {in }}=\dot{Q}_{\text {air }}+\dot{Q}_{\text {fuel }}=\dot{m}_{\text {fuel }}\left[\left.\lambda L_{v t}\left(1+\frac{p_{\mathrm{H}_{2} \mathrm{O}} / p_{\text {amb }}}{1-p_{\mathrm{H}_{2} \mathrm{O}} / p_{\text {amb }}} \frac{M_{\mathrm{H}_{2} \mathrm{O}}}{M_{\text {air }}}\right) \bar{c}_{\text {pair }}\right|_{T_{\text {ref }}} ^{T_{\text {air }}}\left(T_{\text {air }}-T_{r e f}\right)+h_{\text {fuel }}\right]$

$h_{\text {fuel }}=\left.\bar{c}_{p f u e l}\right|_{T_{\text {ref }}} ^{T_{\text {fuel }}}\left(T_{\text {fuel }}-T_{\text {ref }}\right)+H_{u}^{T_{\text {ref }}}-l_{\text {boil }}^{T_{\text {boil }}}-\left(\left.\bar{c}_{\text {liqfuel }}\right|_{T} ^{T_{\text {fuel }}^{\text {boil }}}-\left.\bar{c}_{p f u e l}\right|_{T_{f u e l}} ^{T_{\text {boil }}}\right)\left(T_{\text {boil }}-T_{\text {fuel }}\right)$

$H_{u}^{T_{r e f}}=H_{u}^{T_{H_{u}}}-\frac{\dot{m}_{\text {fuel }}+\dot{m}_{\text {air }}}{\dot{m}_{\text {fuel }}}\left(\left.\bar{c}_{\text {pexh }}\right|_{T_{H_{u}}} ^{T_{\text {ref }}}-\left.\bar{c}_{\text {pmix }}\right|_{T_{H_{u}}} ^{T_{\text {ref }}}\right)\left(T_{\text {ref }}-T_{H_{u}}\right)$

The fuel enthalpy depends on the fuel phase and its lower heating value at a reference temperature. The fuel vaporization heat at boiling temperature is considered as positive in this equation. In the case of gaseous fuel the last two components of equation (2) are not taken into account. By means of computational tool [1] it was verified that it is appropriate to choose the ambient temperature as a reference temperature. Heat flux to the coolant is given by equation (4).

$\dot{Q}_{\text {cool }}=\left.\dot{m}_{\text {cool }} \bar{c}_{\text {cool }}\right|_{T_{\text {cool } 2}} ^{T}\left(T_{\text {cool } 1}-T_{\text {cool } 2}\right)$

However, the calculated coolant heat flux is often accompanied by the strong influence of both measured temperature error and coolant flow error. The total energy flow of the exhaust gas comprises the kinetic, thermal and chemical energy of unburned fuel. The total thermal energy flow is calculated from the total (stagnation) enthalpy flow rate.

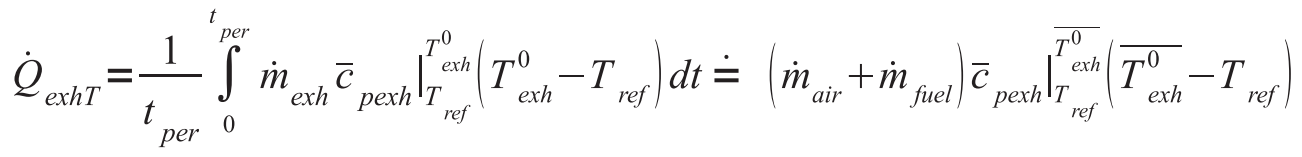

In practice it is not possible to measure instantaneous stagnation exhaust gas temperature and mass flow rate simultaneously. Therefore a substantial simplification is applied. This leads to a lower calculated heat flow compared to reality [2].

The energy flow due to unburned fuel (incomplete combustion) is given by (6),

$\dot{Q}_{\text {exhU }}=\dot{m}_{f u e l} H_{u}^{25^{\circ} \mathrm{C}}\left(1-\eta_{c}\right)$

where the combustion efficiency is calculated according to the general approximation formula [3].

$\eta_{c}=1,3733 \lambda-0,3733 \quad \forall \lambda<1$

$\eta_{c}=1 \quad \forall \lambda \geq 1$

Despite its simplicity, this function corresponds sufficiently well to the experimental data. As a result of the heat balance study at various air fuel ratios, the results presented in Figure 2 were obtained. The measurement was carried out at various engine speeds and loads. 


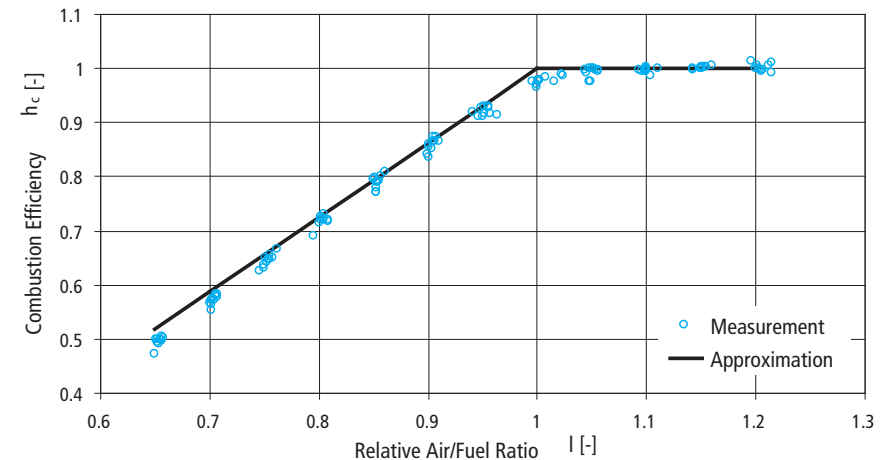

FIGURE 2: Comparison of measured and approximated combustion efficiency. OBRÁZEK 2: Porovnání měřené a aproximované účinnosti hoření.

The heat flux due to convection and radiation from the engine surface is hard to determine by direct measurement. Therefore the following relationship is used for this purpose

$\dot{Q}_{m i s c}=\dot{Q}_{i n}-P_{e f}-\dot{Q}_{c o o l}-\dot{Q}_{e x h T}-\dot{Q}_{e x h U}$

Thus, the convection and radiation heat flux is given with respect to the other measurable heat flows. All the above-stated specific heats are applied as functions of temperature and air/ fuel mixture composition if needed.

\section{DIFFICULTIES OF HEAT BALANCE CALCULATION}

The radiation heat flux is usually estimated according to the formula (8). Such estimation involves convection, radiation and all the errors and uncertainties of the measurement. In order to divide these heat flows, contactless measurement of the engine surface temperature was performed using an FLIR IR camera. A 4-cylinder in-line SI passenger car engine was chosen as a subject for the investigation. In addition to common quantities, 3 additional temperature measurement points were added on the surface of the engine (on the crankcase and on the cylinder head cover). The setting of the IR camera was checked according to readings from these temperature sensors. To avoid the application of an incorrect value of the emissivity the entire engine was sprayed with a special paint having a precisely defined emissivity of $\varepsilon=0.96$. Long-lasting temperature stabilization is especially important for this kind of measurement. It takes several minutes after a change to the speed and engine load. If the change is considerable, then a quarter of an hour is not unusual. The surface of the engine was divided into areas in which a similar temperature was expected (the oil pan, the crankcase with the cooling jacket, the rest of the crankcase, the front cover of the valve train drive, the cylinder head on the side of the exhaust and of the intake manifold, the cover of the cylinder head). Their mean temperatures were determined on the basis of measurements with the IR camera. The radiation heat flux was calculated according to StefanBoltzmann's equation with respect to surrounding temperatures and reciprocal radiation. The convective heat flux was calculated using formulas for natural convection as it is impossible to determine the conditions of the air flow around the engine in the test cell. After the evaluation of convection and radiation heat flux, the residual heat flow was calculated according to the formula

$\dot{Q}_{\text {res }}=\dot{Q}_{\text {in }}-P_{e f}-\dot{Q}_{\text {cool }}-\dot{Q}_{e x h T}-\dot{Q}_{e x h U}-\dot{Q}_{\text {rad }}-\dot{Q}_{c o n v}$

where the residual heat flow in this context represents all measurement and calculation errors. The other heat flows were calculated using an Excel file macro [4].

\subsection{MEASUREMENT RESULTS}

Figure 3 shows individual heat flows and their relative proportion in relation to the incoming energy flow. It is evident that the heat flux of the radiation and the convection doesn't affect the residual heat significantly. It is even difficult to recognize this value in the chart because the corresponding increment is an order of magnitude lower compared to the others. The total heat flux of radiation and convection represents less than $1 \%$ of the incoming energy.

\subsection{RESIDUAL HEAT AND MEASUREMENT ERRORS}

The main errors are similar for all measurements of the heat balance. The heat flux to the coolant is affected in particular by the accuracy of the coolant temperature reading because the difference of the inlet and outlet temperature is only few degrees Kelvin. Even a deviation of $0.1 \mathrm{~K}$ can cause an error of several percent. During the coolant flow measurement it is necessary to prevent air or steam bubbles. The main problem of the exhaust gas energy calculation is the high fluctuation of temperature and mass flow during one working cycle.

The above-stated measurements were particularly focused on the heat flux of the radiation and the convection. Their evaluation is influenced by many parameters and unknowns having a significant impact, and it is impossible to take direct measurements of all the required values. This task was performed with the respect to natural convection only, but in fact a certain degree of air movement is always present in the test cell. The applied heat transfer coefficients were between 4.2 and $5.2 \mathrm{~W} / \mathrm{m}^{2} \mathrm{~K}$, which correspond to the typical values [5]. The engine surface is also dissected and it is a problem to determine the temperature of some sections because they are, for instance, hidden under the inlet manifold. The temperatures determined 
by the IR camera are significantly influenced by the shape of the surface and the inclination angle, reflected temperatures from other surrounding objects and by the calibration parameters. Nevertheless, in general terms it is possible to say that the resulting values of the radiation and convection are not far from the real values. However, the major portion of the residual heat remains undistributed. The suspicion that applied fuel lower heating value of $43.5 \mathrm{MJ} / \mathrm{kg}$ is higher than is really the case is plausible.

\section{HEAT FLUX TO COOLANT}

One of the most important outputs of the heat balance is the heat flux to the coolant. This parameter influences the design of the vehicle front-end and also the main heat exchanger.

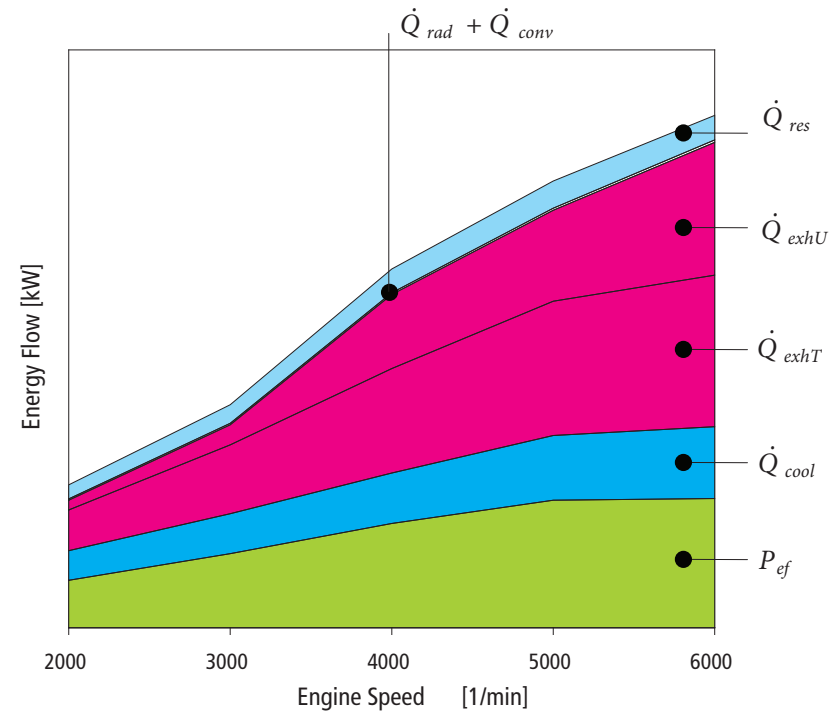

FIGURE 3: Energy balance of a 4-cylinder SI engine at full load.

OBRÁZEK 3: Tepelná bilance 4-válcového zážehového motoru při plném zatí̌ení.

\subsection{ENGINES}

Figure 4 shows the typical relationship between the useful portion of fuel energy and heat flux to the coolant for $\mathrm{Cl}$ (compression-ignition) engines. The points on the graph are taken from the engine map measurement, which consists of about 200 operating points at various engine speeds and loads. The useful portion of the fuel energy is given by the following simplified formula

$E_{\text {fuel }}=\dot{m}_{\text {fuel }} H_{u}^{25^{\circ}} \eta_{c}$

The curve obtained at full engine load corresponds to the upper envelope of the measured points. This is caused by increasing of the relative air/fuel ratio along with decreasing engine load and thus lowering of combustion temperatures.

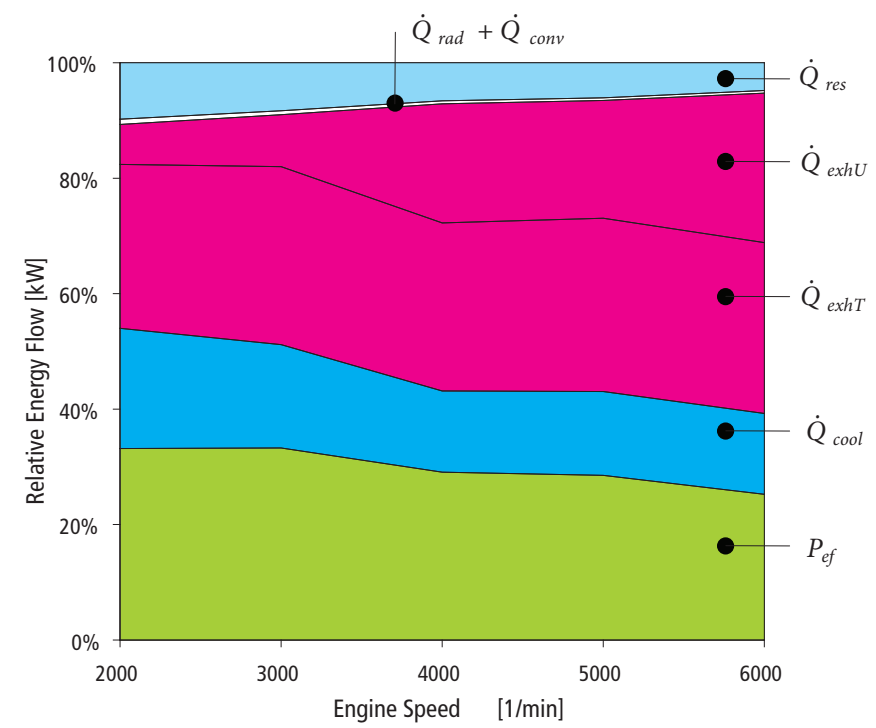

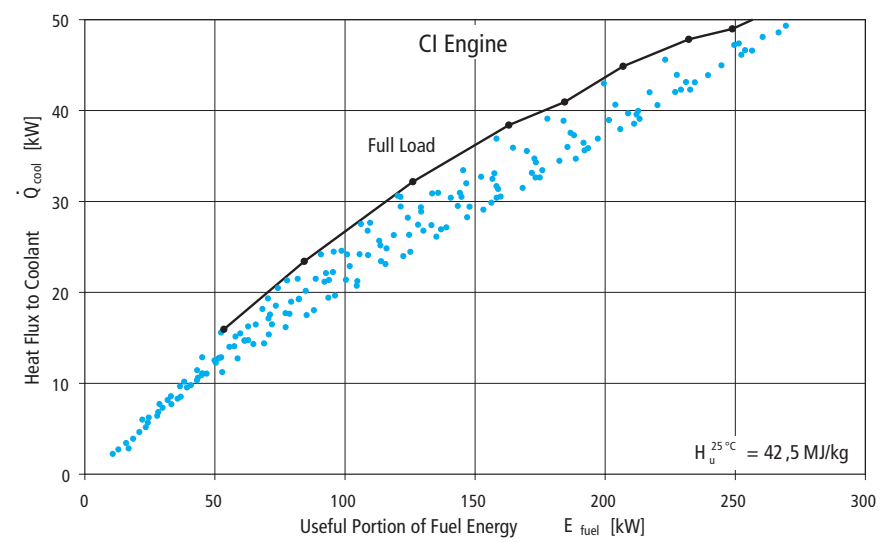

FIGURE 4: Heat flux to coolant as a function of the useful portion of fuel energy for a $\mathrm{Cl}$ engine.

OBRÁZEK 4: Tepelný tok do chladící kapaliny v závislosti na využitelné energii z paliva pro vznětový motor.

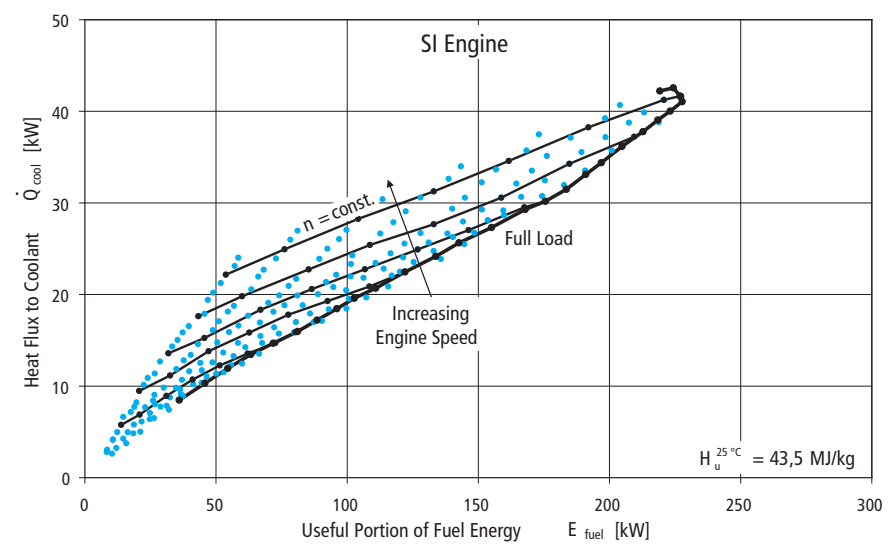

FIGURE 5: Heat flux to coolant as a function of the useful portion of fuel energy for an SI engine.

OBRÁZEK 5: Tepelný tok do chladící kapaliny v závislosti na využitelné energii z paliva pro zážehový motor. 


\subsection{SI ENGINES}

The distribution of measured points for SI (spark-ignition) engines differs significantly from $\mathrm{Cl}$ engines. Figure 5 shows the typical relationship between the useful portion of fuel energy and heat flux to the coolant. The measurements were recorded at various speeds and engine loads for a total of 240 operating points.

The useful portion of the fuel energy is again calculated using equation (10). The points at full engine load form the lower envelope of all measured points, contrary to $\mathrm{Cl}$ engines. The curves of constant engine speeds are nearly parallel. This is the typical behavior of common SI engines with homogenous mixture formation at a relative air/fuel ratio close to 1. However, if the constant speed points are not linked, the measured points are non-uniformly scattered.

During the last decade several types of gasoline engine have been investigated. To be able to identify irregular measured points for SI engines the following approximation was established

$\dot{Q}_{\text {cool }}=A n^{0.46}\left(\dot{m}_{\text {fuel }} H_{u}^{25^{\circ} C} \eta_{c}\right)^{0.51}$

where $A$ is a constant which differs for particular engines. For the calculation of predicted heat flux to the coolant only common quantities are used. For determination of the constant A two measured points are sufficient, but it is preferable to use a regression method. This empirical equation considers several engine types, including a turbocharged engine. The

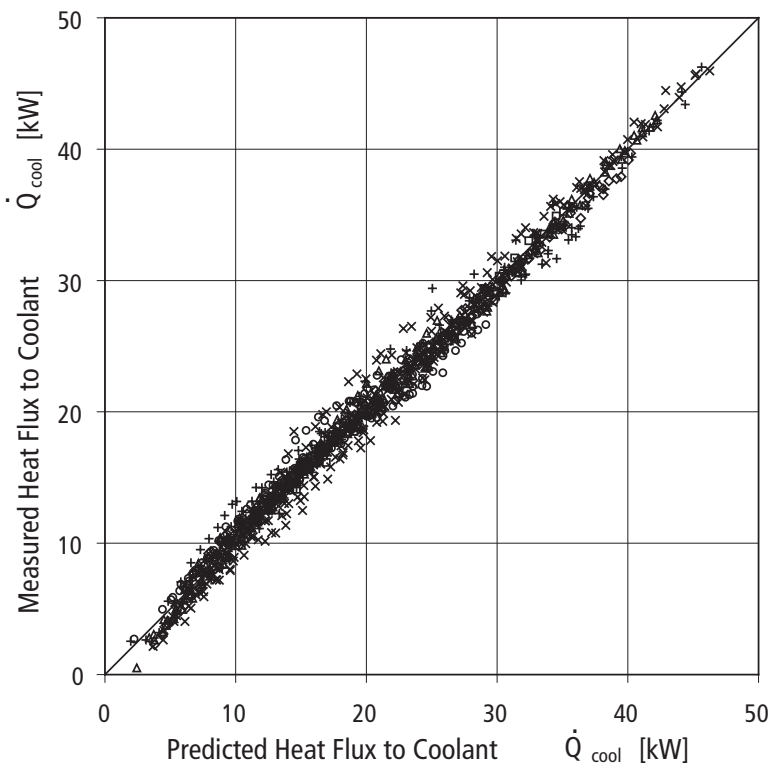

FIGURE 6: Correlation between measured and predicted heat flux (eq. (11)) to coolant for several SI engines.

OBRÁZEK 6: Vzájemná korelace mezi změřeným a vypočteným tepelným tokem (dle vztahu (11)) do chladící kapaliny pro několik zážehových motorů. stated exponents were determined from measured data using a mathematical regression method. For this purpose equation (11) was rewritten to the linearized form and the exponents were obtained by least-squares matching. Figure 6 shows the relationship between measured values of the heat flux to the coolant and calculated ones using equation (11). There is a very good correlation between these values. The correlation coefficient is 0.994. Although the exponents can differ from engine to engine slightly, the equation (11) can be used effectively for the detection of irregular measured points. In the case of irregular measurements the points spread out considerably away from the center line. However, the heat flux to the coolant can be influenced by ignition advance, air/fuel ratio and others. Then the point can deviate from the center line naturally.

The proposed equation (11) can be embedded in an automated engine testing system. By means of this equation irregular measured values can be revealed even during the early phase of measurement procedure. The equation can also be used for estimation or correction of very low heat flows where there is a serious risk of measurement error due to a small temperature difference at the heat exchanger.

\subsection{CALCULATION CHECK}

The above-stated correlations were checked using the GTPower simulation tool. Figure 7 shows the GT model which was assembled for the real 3-cylinder naturally aspirated $\mathrm{SI}$ engine. Model parameters were given by the engine map measurement. Essential engine parameters along with incylinder pressure indication were measured. Load points at 2000, 3000, 4000 and 4800 rpm were chosen for GT-case settings. The burn rates at these operation points (Figure 8) were computed using the AVL Indicom procedure utilizing Woschni's formula for the wall heat transfer calculation. In the next step the measured burn rate was substituted by the multiWiebe formula and then placed into the GT computation. The Woschni GT heat flux correlation was chosen for the gas to wall heat transfer calculation.

Following output channels were used in GT-post for the verification:

- Fuel Power, Useful Portion - this represents the part of the fuel which is converted into heat in the combustion chamber.

- Total Heat Transfer Coolant to Structure - this value represents the heat flux from the gas side surfaces to the water jacket of the cooling system.

- Total Heat Transfer Oil to Structure - this value represents the heat flux from the gas side surfaces to the oil system.

- Friction Power - gives the power losses in the engine mechanism. 


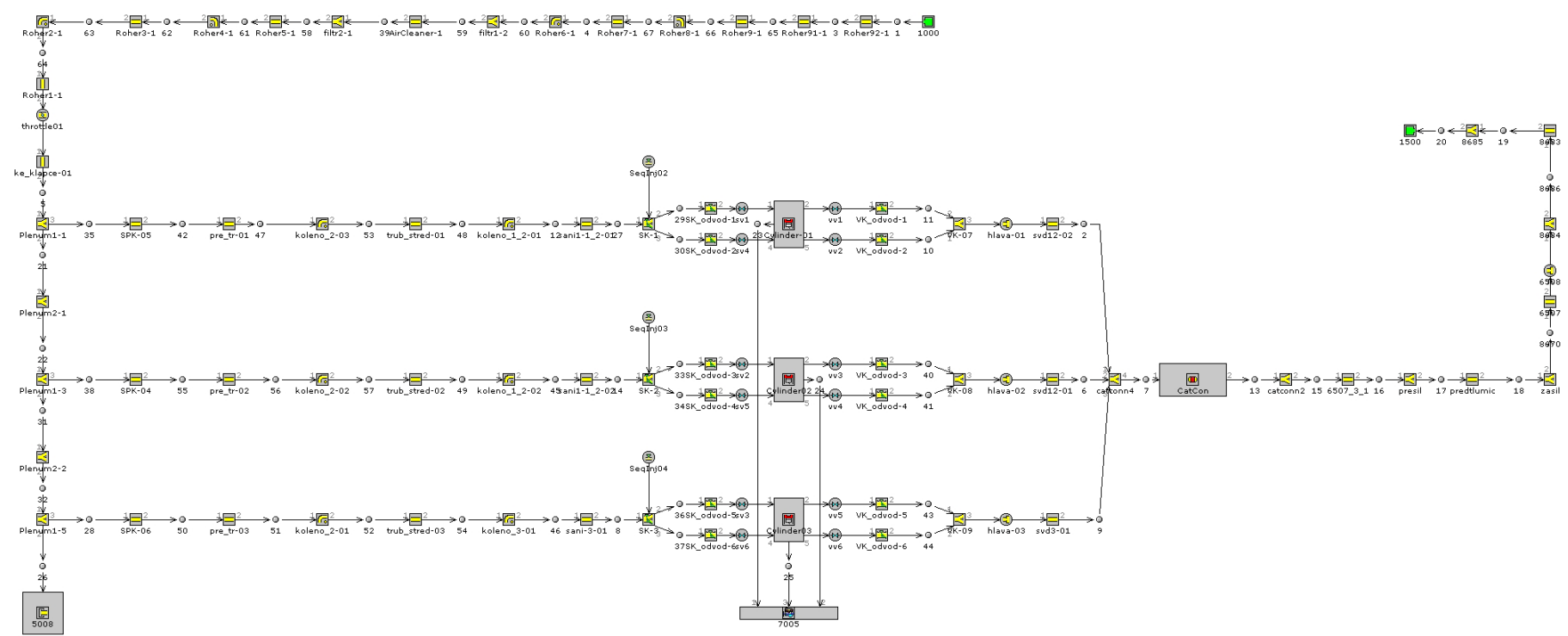

FIGURE 7: GT-Power verification model.

OBRÁZEK 7: Kontrolní model v GT-Poweru.

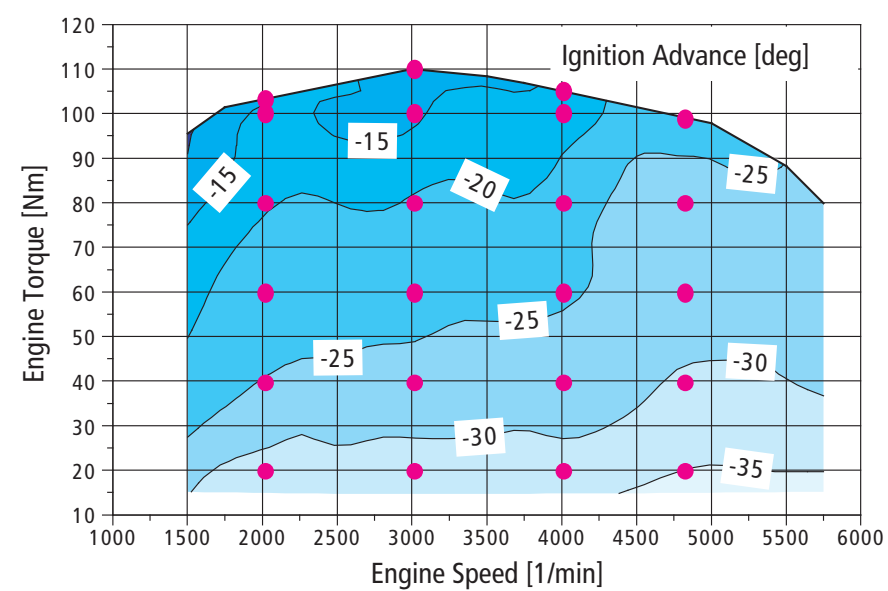

FIGURE 8: Selected calculation points and approximated burn rate curve. OBRÁZEK 8: Vybrané body pro výpočet a aproximace průběhu hoření.

Figure 9 shows the comparison between the real engine measurements and GT results for selected points. The graph shows the heat exchange in the water cooler. Since it is calculated using the GT-Power tool, the standard results of the coolant heat flux represent the heat transfer to the water jacket of the cylinder liner and cylinder head. The values in the graph are given by the sum of Total Heat Transfer Coolant to Structure and a portion of the Total Heat Transfer Oil to Structure and Friction Power. Calculation results show relatively good agreement with the measurements. The best conformity is in the middle of the load range. However, calculated curves have a steeper slope compare to the measured trend. This may be caused by variable coolant-side heat transfer coefficients in reality, while the GT model coefficients are the same for all computed cases. It is also

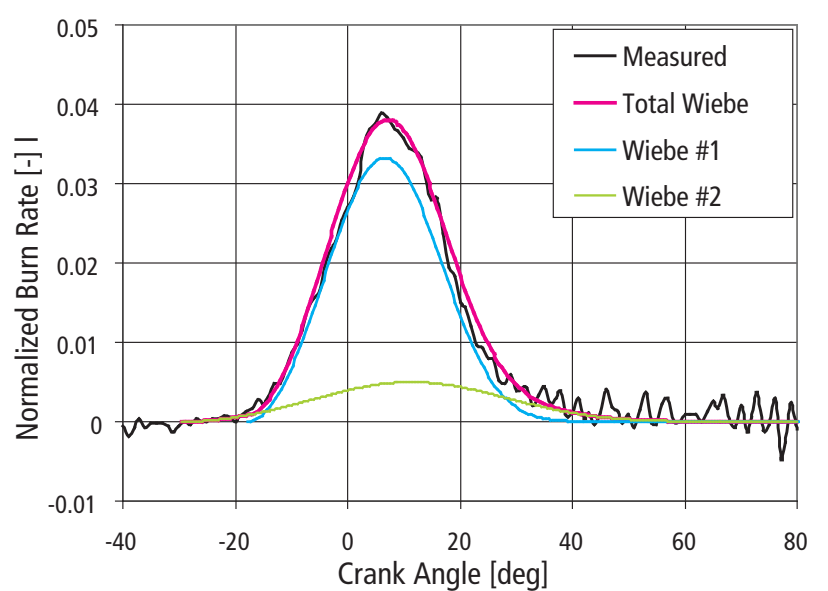

possible that applied approximation of gas-wall heat transfer coefficient does not perfectly represent the real situation.

The main task of this calculation was to compare the GT results with approximation formula (11). The linearity coefficient was obtained by least-square matching, the particular value was $A=1.327$. Figure 10 shows the correlation between approximated and calculated heat flux to the coolant. The used approximation gives the correct trend with correlation coefficient 0.985 .

\subsection{RECENT TRENDS}

The comparison between different engine types at full load is shown in Figure 11. Two possible representations of relative coolant heat flux are shown. Generally, the relative heat flux to the coolant decreases with engine speed. However, the measured 


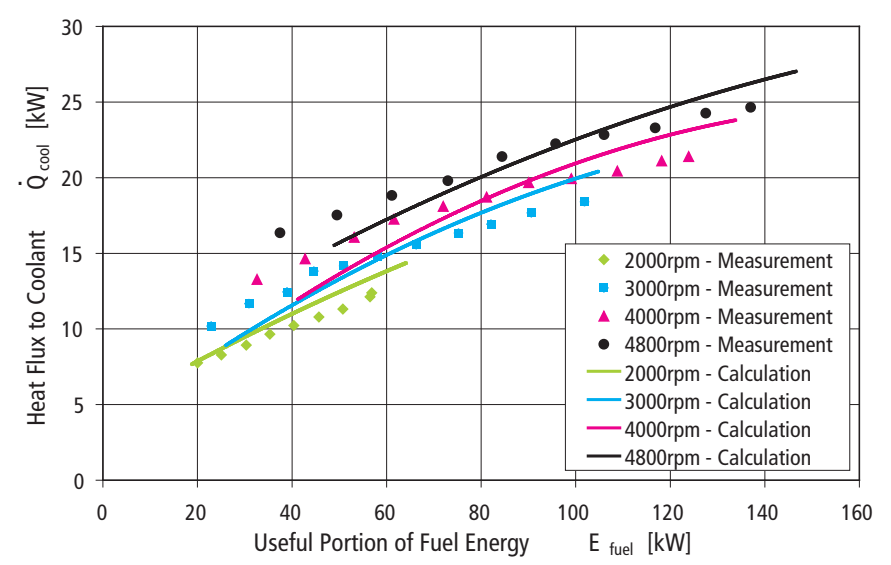

FIGURE 9: Comparison of measurement and calculation of heat flux to coolant.

OBRÁZEK 9: Porovnání změřených a vypočtených tepelných toků do chladící kapaliny.

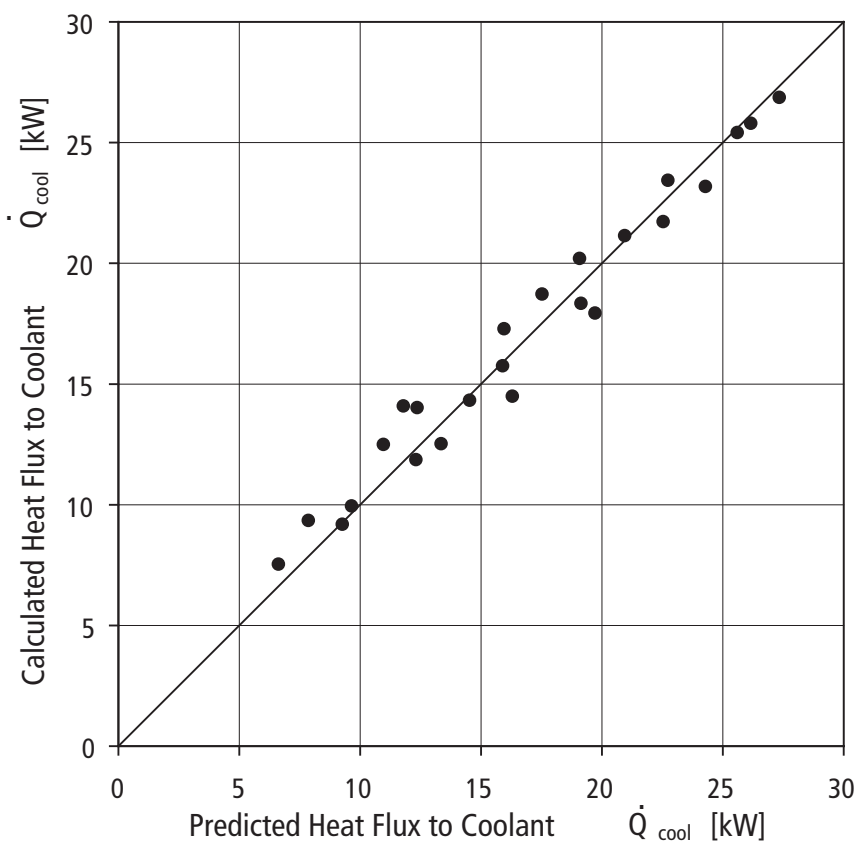

FIGURE 10: Correlation between calculated and predicted heat flux (eq.

(11)) to coolant.

OBRÁZEK 10: Vzájemná korelace mezi vypočteným a odhadnutým tepelným tokem (dle vztahu (11)) do chladící kapaliny.

values of the heat flux are smaller than stated in [6]. Typical values of the coolant heat flux range from 10 to $20 \%$ of incoming energy flow for $\mathrm{SI}$ engines. The heat transfer to the coolant for $\mathrm{Cl}$ engines is naturally higher. It ranges from 20 to $30 \%$ of engine total energy flow rate at full load. These measurements were carried out with different coolants. The used coolant varied from pure water to a glycol mixture. It was found that using the pure water increases the heat flux by $5 \%$ (not the percentage points in Figure 11) compared to the blended antifreeze mixture of ratio 1:1. SI engines of an older design have a higher coolant heat flux. A recent trend in the automotive industry is to design engines with lower heat transfer to the coolant in order to reduce heat losses. Generally, the heat exchange surface of the cylinder liner is reduced and/or coolant temperature control set point rises. On the other hand the coolant is heated up from exhaust gas in order to reduce high reaction temperatures in the catalytic converter. Finally, the heat flux to the coolant remains more or less the same.

\section{CONCLUSION}

Taking measurements and subsequent calculation to provide a complete evaluation of the engine energy balance is a very tricky task. It is influenced by many factors associated with the measurements itself. Although the radiation and natural convection from the engine surface is negligible, there often remains a relatively large portion of undistributed residual heat. This comprises partly the exhaust gas energy and the measurement errors, or it may be caused by the wrong choice of fuel lower heating value. An empirical formula for the heat flux to the coolant for SI engines was proposed. The calculation using the GT-Power tool confirmed the applicability of this approximation. It can be used for fast and efficient detection of irregular measured points, even during an automated acquisition procedure.

\section{LIST OF NOTATIONS AND ABBREVIATIONS}

$\left.\left.\bar{c}_{\text {pair }}\right|_{T_{1}} ^{T_{2}}{ }_{1} \bar{c}_{\text {pmix }}\right|_{T_{1}} ^{T_{2}}$ Mean air, mixture specific heat at constant pressure in temperature range [J/kgK]

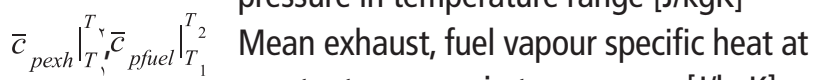
constant pressure in temp. range $[\mathrm{J} / \mathrm{kgK}]$

$\left.\bar{c}_{\text {liqfuel }}\right|_{T_{1}} ^{T_{2}},\left.\bar{c}_{c o o l}\right|_{T_{2}} ^{T_{1}} \quad$ Mean liquid fuel, coolant specific heat in temperature range $[\mathrm{J} / \mathrm{kgK}]$

$E_{\text {fuel }} \quad$ Useful portion of fuel energy [W]

$h_{\text {air }}, h_{\text {fuep }} h_{\text {exh }} \quad$ Air, fuel, exhaust specific enthalpy [J/kgK]

$H_{u}^{\text {Tref }} \quad$ Fuel lower heating value at reference temperature and constant pressure $[\mathrm{J} / \mathrm{kg}]$

$I_{\text {boil }}^{T_{\text {boil }}} \quad$ Fuel vaporization heat at boiling temperature [K]

$L_{y t} \quad$ Stoichiometric dry air/fuel ratio $[\mathrm{kg} / \mathrm{kg}]$

$\dot{m}_{\text {air }}, \dot{m}_{\text {exh }} \quad$ Air, exhaust mass flow rate $[\mathrm{kg} / \mathrm{s}]$

$\dot{m}_{\text {fuel }}, \dot{m}_{\text {cool }} \quad$ Fuel, coolant mass flow rate $[\mathrm{kg} / \mathrm{s}]$

$M_{\text {air }}, m_{\mathrm{H}_{2} \mathrm{O}} \quad$ Air, water vapour molecular weight $[\mathrm{kg} / \mathrm{mol}]$

$n \quad$ Engine speed [1/min]

$p_{a m b} \quad$ Ambient pressure $[\mathrm{Pa}]$

$p_{\mathrm{H}_{2} \mathrm{O}} \quad$ Ambient water vapour partial pressure [Pa]

$P_{e f} \quad$ Effective power [W]

$\dot{Q}_{\text {exhT }} \quad$ Exhaust thermal heat flow rate [W]

$\dot{Q}_{\text {exhu }} \quad$ Exhaust energy flow rate due to unburned fuel (incomplete combustion) [W]

$\dot{Q}_{\text {in }} \quad$ Total energy flow rate to engine [W] 

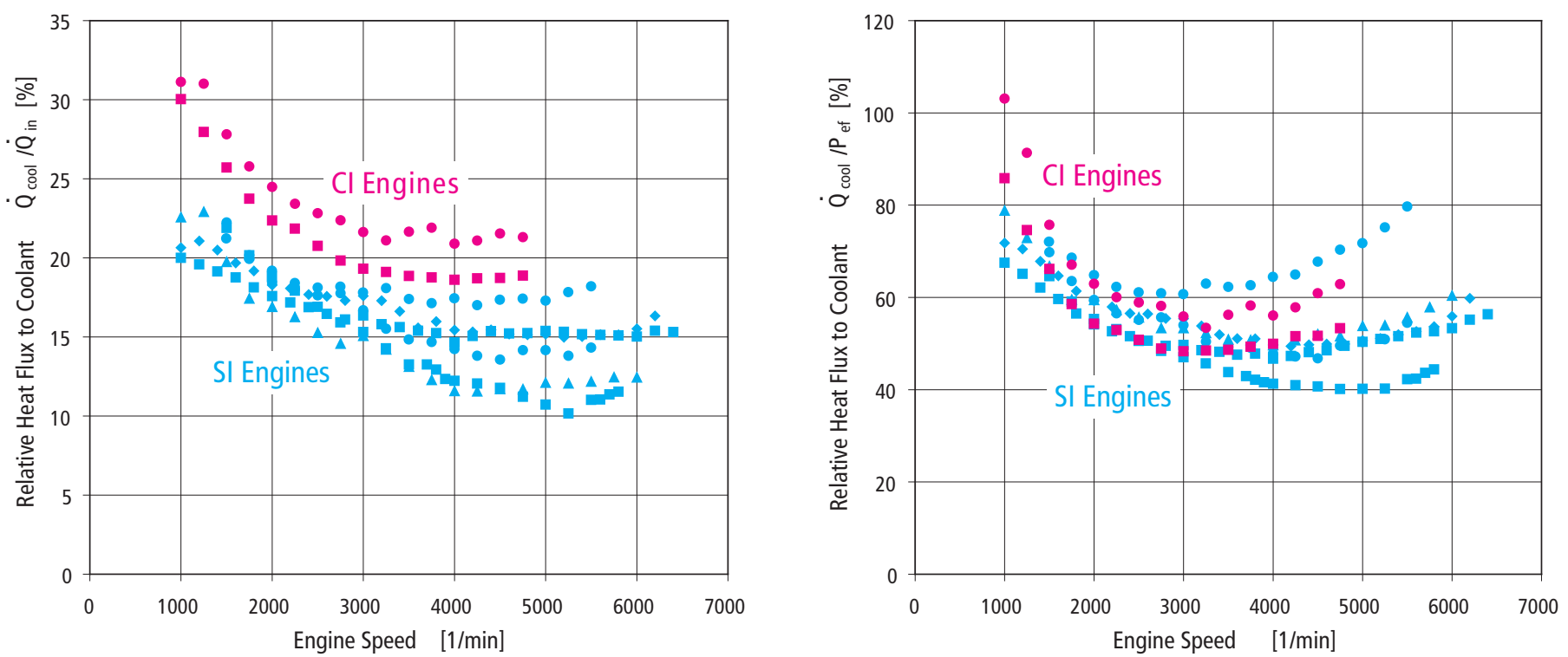

FIGURE 11: Relative heat flux to coolant at full engine load as a function of engine speed.

OBRÁZEK 11: Relativní tepelný tok do chladící kapaliny při plném zatí̌ení motoru v závislosti na otáčkách motoru.

$\dot{Q}_{\text {conv }} \dot{Q}_{\text {rad }}$

$\dot{Q}_{\text {cool }}$

$\dot{Q}_{\text {res }}$

$t_{\text {per }}$

$T_{\text {air }}^{\text {per }}, T_{\text {fue }}$

$T_{\text {exh }}^{0}$

$T_{e x h}^{0}$

$T_{\text {boil }}$

$T_{r e f}$

$T_{\text {cool } 1}, T_{\text {cool } 2}$

$\lambda$

$\eta_{c}$
Convective, radiation heat flow rate [W]

Heat flux to coolant [W]

Residual heat flow rate [W]

Period time [s]

Air, fuel temperature [K]

Instantaneous exhaust stagnation temperature

$[\mathrm{K}]$

Time averaged exhaust stagnation temperature

[K]

Fuel boiling temperature [K]

Reference temperature [K]

Outlet, inlet coolant temperature from/to engine

[K]

Relative dry air/fuel ratio [-]

Combustion efficiency [-]

\section{REFERENCES}

[1] Páv K. (2012). Simulace pracovního oběhu 4T, Computational Tool.

[2] Vávra J., Macek J., Vítek O., Takáts M. (2007). Modeling of Sensor Performance during Engine Testing, SAE World Congress.

[3] Grill M. (2006). Objektorientierte Prozessrechnung von Verbrennungsmotoren, Institut für Verbrennungsmotoren und Kraftfahrwesen der Universität Stuttgart, p. 80.

[4] Páv K. (2012). Tepelná bilance motoru, Computational Tool, 2012.

[5] Urbášek J. (1985). Teoretické základy energetických zařizení - Tabulky a diagramy termofyzikálních vlastností látek, VŠsT Liberec.

[6] Heywood J. B. (1988). Internal Combustion Engine Fundamentals, McGraw-Hill, p. 673. 